\title{
Fontan survival: As good as it gets?
}

\author{
Poonam Thankavel, MD, ${ }^{\mathrm{a}}$ and Robert D. B. Jaquiss, $\mathrm{MD}^{\mathrm{b}}$
}

\footnotetext{
From the ${ }^{\mathrm{a}}$ Division of Cardiology, Department of Pediatrics, and the ${ }^{\mathrm{b}}$ Section of Pediatric and Congenital Heart Surgery, Department of Cardiovascular and Thoracic Surgery, Children's Medical Center/UT Southwestern Medical Center, Dallas, Tex.

Disclosures: Authors have nothing to disclose with regard to commercial support.

Received for publication March 17, 2017; accepted for publication March 21, 2017; available ahead of print April $20,2017$.

Address for reprints: Robert D. B. Jaquiss, MD, Section of Pediatric and Congenital Heart Surgery, Department of Cardiovascular and Thoracic Surgery, Children's Medical Center/UT Southwestern Medical Center, 1935

Medical Center Dr, Dallas, TX 75235 (E-mail: Robert.jaquiss@utsouthwestern.edu).

J Thorac Cardiovasc Surg 2017;154:241-2

$0022-5223 / \$ 36.00$

Copyright (C) 2017 by The American Association for Thoracic Surgery

http://dx.doi.org/10.1016/j.jtcvs.2017.03.114
}

Survival for children with univentricular hearts has greatly improved since Fontan and Baudet ${ }^{1}$ and Kreutzer and colleagues $^{2}$ described effective surgical palliation almost 4 decades ago, with initial early failure rates near $15 \% .^{3,4}$ Improvements in patient selection, surgical techniques, and perioperative management have resulted in contemporary early mortalities of less than $5 \%, 3,5,6$ with the focus now shifting toward identification of modifiable factors that may improve long term outcomes.

Downing and colleagues ${ }^{7}$ provide updated outcome data for a "modern" Fontan cohort, specifically including a substantial proportion of patients with single right ventricles, capturing eras during which Fontan completion strategy evolved from the lateral tunnel version to the extracardiac conduit approach. Survival was analyzed in 773 patients who underwent Fontan operations during a 20-year period, with spectacularly complete (>99\%) follow-up obtained by combining local records with data from the National Death Index and the Scientific Registry of Transplant Patients. To demonstrate practice evolution, the cohort was divided into eras: 1992 through 1996, 1997 through 2002, and 2003 through 2009. A composite negative outcome variable included Fontan takedown, heart transplant, or death. Freedoms from this outcome were $94 \%$ at 1 year, $90 \%$ at 10 years, $85 \%$ at 15 years, and $74 \%$ at 20 years. Early outcomes improved as the eras progressed, but, disappointingly, late survival did not. Risk factors for early ( $<1$ year) adverse outcomes include prolonged pleural drainage ( $>2$ weeks), intensive care unit stay longer than 1 week, Fontan operation before 1997, preoperative mild or worse atrioventricular valve regurgitation (AVVR), and longer aortic crossclamp times, with adverse late outcome associated with mild or worse AVVR and post-Fontan intensive care unit stay longer than 1 week. Heterotaxy, ventricular morphology, and the presence of a common atrioventricular valve were not risk factors for adverse late outcome. Among patients undergoing pre-Fontan catheterization $(87 \%$ overall, but only $76 \%$ in the most recent era), mean pulmonary arterial pressure greater than

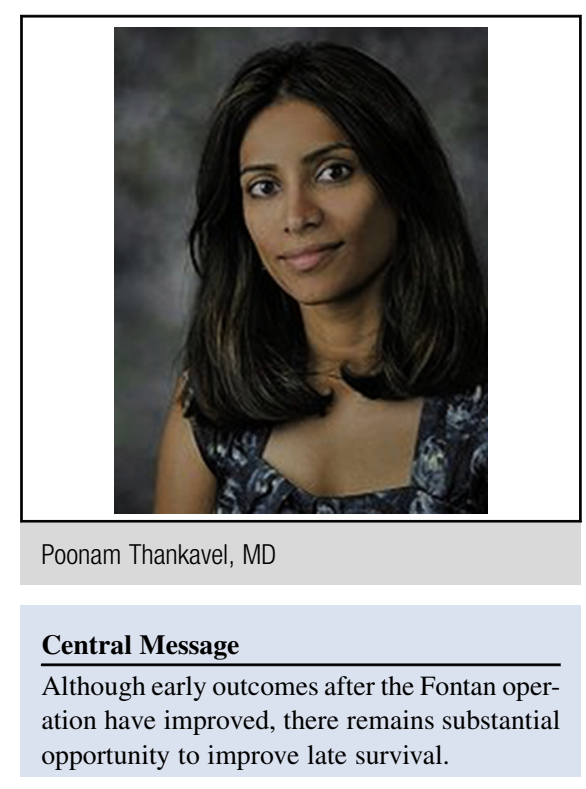

See Article page 243.
$15 \mathrm{~mm} \mathrm{Hg}$ was a risk factor for early but not late adverse outcome.

The impact of AVVR was surprising and important given its high prevalence, increasing from $35 \%$ to $41 \%$ to $56 \%$ through the eras and accounting for $45 \%$ of the entire cohort. This is an interesting observation, given that half of patients with AVVR were in the mild category, not previously recognized as a high-risk subset. ${ }^{8}$ Indeed, evaluation of tricuspid valvuloplasty or replacement has focused on those with at least moderate regurgitation., ${ }^{9,10}$ Whether AVVR is a modifiable risk factor or simply a marker of worse Fontan candidacy remains to be elucidated.

The negative late implication of prolonged hospitalization was not unexpected but may raise concern at the institution of Downing and colleagues ${ }^{7}$ in light of the increases between the second and third eras in length of stay, length of pleural drainage, and incidence of drainage lasting longer than 14 days. Whether these changes reflect a 10-month older age at operation in the third era and the decision to omit catheterization in $25 \%$ of patients is not clear. It might be speculated that prolonged cyanosis results in more systemic to pulmonary collateral blood flow, longer effusions, and so on. Like all good studies, this report answers some questions, raises others, and points us toward possible improvement. 


\section{References}

1. Fontan F, Baudet E. Surgical repair of tricuspid atresia. Thorax. 1971;26: 240-8.

2. Kreutzer G, Galindez E, Bono H, De Palma C, Laura JP. An operation for tricuspid atresia. J Thorac Cardiovasc Surg. 1973;66:613-21.

3. Van Arsdell GS, McCrindle BW, Einarson KD, Lee KJ, Oag E, Caldarone CA, et al. Interventions associated with minimal Fontan mortality. Ann Thorac Surg. 2000;70:568-74.

4. Knott-Craig CJ, Danielson GK, Shaff HV, Puga FJ, Weaver AL, Driscoll DD. The modified Fontan operation: an analysis of risk factors for early postoperative death or takedown in 702 consecutive patients from one institution. J Thorac Cardiovasc Surg. 1995; 109:1237-43.

5. Mair DD, Puga FJ, Danielson GK. The Fontan procedure for tricuspid atresia: early and late results of a 25-year experience with 216 patients. J Am Coll Cardiol. 2001;37:933-9.
6. Dabal RJ, Kirklin JK, Kukreja M, Brown RN, Cleveland DC, Eddins MC, et al. The modern Fontan operation shows no increase in mortality out to 20 years: a new paradigm. J Thorac Cardiovasc Surg. 2014;148:2517-23.

7. Downing TE, Allen KY, Glatz AC, Rogers LS, Ravishankar C, Rychik J, et al. Long-term survival after the Fontan operation: twenty years of experience at a single center. J Thorac Cardiovasc Surg. 2017;154:243-53.e2.

8. Barber G, Helton JG, Aglira BA, Chin AJ, Murphy JD, Pigott JD, et al. The significance of tricuspid regurgitation in hypoplastic left-heart syndrome. Am Heart J. 1988;116:1563-7.

9. Reyes A II, Bove EL, Mosca RS, Kulik TJ, Ludomirsky A. Tricuspid valve repair in children with hypoplastic left heart syndrome during staged surgical reconstruction. Circulation. 1997;96(9 Suppl):II341-3; discussion II 344-5.

10. Elmi M, Hickey EJ, Williams WG, Van Arsdell G, Caldarone CA, McCrindle BW. Long-term tricuspid valve function after Norwood operation. J Thorac Cardiovasc Surg. 2011;142:1341-7.e4. 